\title{
Blokker, Paul: New Democracies in Crisis? A Comparative Constitutional Study of the Czech Republic, Hungary, Poland, Slovakia and Romania.
}

London: Routledge, 2014, xii, 200 stran, ISBN: 978-0-203-79502-6.

Jiř́ Baroš ${ }^{1}$

Slavný americký levicový politický teoretik Sheldon S. Wolin kdysi napsal, že demokracie má prchavou (fugitive) povahu (Wolin 1994; Wolin 2004: 601-606). Př́ležitostně se objeví, nicméně je chybou považovat ji za ústavní formu pro celou společnost. Demokracie je dle Wolinspíše projektem, který probouzí potenciál běžných občanů. Ti se politickými bytostmi stanou teprve až skrze objev toho, že se určité věci dotýkají jich všech, a skrze společné jednání za účelem dosažení těchto věcí. Naproti tomu ,ústavní demokracie“ je demokracií bez lidu jakožto aktéra; je to ústava, která klade limity demokracii, reguluje množství demokratické politiky, již dovolí. Ve větší či menší návaznosti na Wolina se v poslední době v rámci teorie konstitucionalismu objevily nové teoretické př́stupy, které kritizují zapouzdření moderní politiky do ústavních forem. ${ }^{2}$ Mezi nepř́ijemné důsledky tohoto zapouzdření patři i námi zakoušené mizení demokracie. Podle Wolina je demokracie především o zkušenosti politiky, které se stále více lidem nedostává.

Význam recenzované knihy sociologa Paula Blokkera, který působí na univerzitě v italském Trentu a dlouhodobě se věnuje fenoménu konstitucionalismu ve Střední Evropě, je dvojí: (1) jednak nabízí dobrý přehled současných konstitucionalistických př́stupů a zároveň (2) tuto teoretickou debatu aplikuje na jím zkoumané země: Českou republiku, Mad’arsko, Polsko, Rumunsko a Slovensko. Všechny tyto státy charakterizuje podle Blokkera spíše krize než konsolidace. Ačkoliv může být současná politická a ústavní krize vztahována k důsledkům globální finanční a ekonomické krize, její důležitá dimenze tkví v nevyvážené institucionalizaci demokracie. Jednostranný důraz na formální instituce právního státu a zakotvení demokracie vedl k opomenutí její substantivní, participační a legitimizační dimenze. Převažující chápání demokracie bylo bohužel až př́liš formalistické, elitářské či technokratické. Oproti tomu bylo třeba se demokracii znovu (na)učit, osvojit si praxi demokratické deliberace a více podporovat občanskou angažovanost a participaci. V následujícím textu se zaměřím především na dvě oblasti: nejprve rozeberu Blokkerovo rozčlenění současných konstitucionalismů, abych se následně mohl zamyslet nad aplikací jím preferované varianty konstitucionalismu jako analytického nástroje a normativní představy na českou politiku, a to ve světle tezí některých politických teoretiků, kteří své závěry sice mnohdy nevytvořili na pozorování české reality, ovšem lze je podle mého názoru i na ni vztahovat. Byt' mi bude východiskem diskuse Blokkerových tezí především česká (ne polská apod.) realita, jde o legitimní postoj, jestliže jej budu vztahovat k těm Blokkerovým závěrům, které překládá jako platné pro všechny jím zkoumané země.

Dle Waltera F. Murphyho se ústavní demokracie ve svých politických strukturách snaží vždy zkombinovat (1) vládu lidem (z)volených reprezentantů s (2) komplexním institucionálním

\footnotetext{
${ }^{1}$ Kontakt: Katedra politologie, Fakulta sociálních studií Masarykovy univerzity, Joštova 10, 60200 Brno, Česká republika / Czech Republic. E-mail: baros@fss.muni.cz

2 Srov. k pojmu ústavních forem Mansfield (1991: 193-208). Podle Mansfielda je důraz na ústavní formy v opozici vůči (neformálnímu) populismu; jen formalismus konstitucionalismu ponechává nakonec prostor pro voluntarismus demokracie, ba dokonce umožňuje jeho uvedení do praxe.
} 
uspořádáním, jehož hlavním cílem je omezit a zlepšit vládnutí (Murphy et al. 2008: 45). Reprezentanti lidu musí respektovat určitá substantivní omezení své autority, mezi nimiž mají výlučné postavení základní práva, která se v poválečném konstitucionalismu stala prímo vynutitelným právem. To rozhodujícím způsobem omezilo moc demokratické politiky, jelikož se strážci ústavnosti, a tedy i ochránci základních práv, staly ústavní soudy. Odtud podle Blokkera důraz na jazyk práv(a) ( $\mathrm{v}$ něm se ale podstatná část populace př́liš neorientuje a ani orientovat nechce, nebot' „slušní lidé se přece nesoudíc) a na právní konstitucionalismus, vůči němuž se vymezují zastánci alternativních konstitucionalistických koncepcí. Některé z nich si všímají toho, že kvưli jejich právně-liberálnímu chápání se z ústav nestaly nástroje dialogu o zakládajících hodnotách a právech a o povaze politického společenství, nýbrž toliko nejvyšší právní normy interpretované autoritativními soudními orgány. Právě tento jednostranně právnický prístup přispěl podle Blokkera $\mathrm{k}$ celkové depolitazaci společnosti a juridizaci demokratické politiky. Všechny nové demokracie trpí nedostatečně institucionalizovanou demokraticko-participační dimenzí. Tomu ostatně napomohl též globální trend k právnímu konstitucionalismu, ovšem i mnohovrstevnatá krize reprezentativní demokracie, která se projevuje např. v nárůstu apatie, medializaci politiky, krizi (tradičních) politických stran, poklesu významu rozhodování demokratických institucí kvưli globálním a regionálním právním a regulačním režimům a také kvůli rozsáhlejší devoluci a rozptylu politické moci, čehož důsledkem je to, že jsou politické jednotky nyní daleko slabší.

Ale zpět k různým př́stupům ke konstitucionalismu, které se v současné době vynořily proti dominantnímu právnímu konstitucionalismu. Ten klade v prvé řadě důraz na limity politické moci a garanci právního státu a základních práv. Nástrojem mu jsou specializované instituce ústavních soudů. Problémem právního konstitucionalismu ovšem podle Blokkera je, že pobízí ke skeptickému postoji k občanské angažovanosti. Alternativní konstitucionalismy mu proto vyčítají podceňování sociálních a politických dimenzí ústavy, ze které se stává statický a permanentní rámec rychle se měnící politiky. Jelikož je předpokládán konsensus stran výkladu základních práv, bývají principiální (ústavnî) otázky depolitizovány a ponechány k rozhodování soudním institucím. Podle představitelů politického konstitucionalismu (R. Bellamy, J. Waldron) patří práva mezi pojmy, které jsou bytostně diskutabilní, a proto musí být přístupny přezkoumání ve světle nových názorů. Ústava má být proto toliko rámcem pro artikulaci př́tomnosti více odpovídajících koncepcí těchto pojmů a deliberaci o nich, které by se měli zúčastnit zástupci co nejširš́ho spektra názorů. Jelikož základní ústavní pojmy jsou předmětem neshod, musí ústava nabídnout především mechanismus, jak je (vy)řešit. Nicméně je otázkou, zda politický konstitucionalismus nabízí vhodné řešení krize demokracie, jelikož se nápadně podobá režimu suverenity parlamentu, kvưli jehož selhání se právní konstitucionalismus vlastně objevil. Jsou to navíc reprezentativní instituce, které dnes čelí největší krizi.

Lidový konstitucionalismus se vymezil proti specificky americké variantě právního konstitucionalismu - originalismu. Jeho představitelé (R. Post, R. Siegel, M. Tushnet) vidí $\mathrm{v}$ ústavě otevřenou interpretační strukturu, a proto zpochybňují roli soudů jakožto jejího autoritativního strážce. Samotný lid by měl hrát důležitou roli v ústavněprávní interpretaci. Je totiž klíčové, aby společnost přijala ústavu za svou. Societální konstitucionalismus (G. Teubner), zakotvený $v$ Luhmannově sociologii (práva), chce zase zaměrit pozornost na formy ústavněprávní produkce za hranicemi, ale i uvnitř národního státu. Stát nikdy neintegroval a nekontroloval celou společnost; konstitucionalismus by měl být proto vztažen i k nestátním formám produkce ústavních norem. Podle Blokkera tím však tento př́stup odsouvá stranou 
důležité otázky týkající se konstitutivní moci a kolektivní autonomie. Problémem societálního konstitucionalismu je též strach z politiky; depolitizace ústavy nemůže představovat $\mathrm{v}$ dnešní době řešení krize politiky.

Jako poslední alternativu právnímu konstitucionalismu zmiňuje Blokker jemu nejbližší demokratický konstitucionalismus (J. Colon-Rios, J. Tully), kterému vadí demokratický deficit moderního konstitucionalismu. Důležité ústavní otázky by podle něj měly být řešeny pomocí co nejvíce participačních metod. Zatímco politický a částečně též lidový konstitucionalismus zůstávají uzavřeny $\mathrm{v}$ rámci existujícího ústavního pořádku, demokratický konstitucionalismus svou kritiku zaměřuje vůbec na jeho stavební kameny. Všímá si též globální juridizace, která reprodukuje některé rysy moderního konstitucionalismu. Kromě rozboru demokratického deficitu se demokratický konstitucionalismus pokouší poukázat na nějaké možnosti nápravy, jejíž zárodky vidí v místech, $\mathrm{v}$ nichž se lidé účastní demokratických praktik. Reprezentativní ústavní politika je podle jeho názoru nedostatečná, a proto je třeba hledat daleko otevřenější demokratická uspořádání.

V návaznosti na Jamese Tullyho se Blokker snaží vytvořit vlastní alternativu občanskébo či demokeratizujicího konstitucionalismu, která je ovšem oproti němu zdrženlivější. Měla by ale být inkluzívní, participační, post-fundacionalistická a neuzavřená určitou „věčně pravdivou“ a demokraticky vůbec nerevidovatelnou interpretací základních práv. Na druhou stranu je podle Blokkera demokracie možné demokratizovat. Institucionalizace ústavního pořádku nemusí vyústit ve zcela uzavřený konstitucionalismus, v němž by dominovalo ústavní soudnictví. Existují totiž tři významné oblasti, kde lze uplatnit demokratičtější formy konstitucionalismu: (a) ústavní politika, $\mathrm{v}$ níž by se lid mohl př́ímo podílet na formulaci nejvyšších právních norem (prakticky pak např. formou občanských ústavních shromáždění, lidových ústavních iniciativ nebo lidové tvorby ústavních zákonů) či na ústavních revizích a novelách (např. instituce lidového referenda či lidové iniciativy), (b) přímá demokracie (týkající se jak ústavních dodatků, tak přijímání nové ústavy, ale i běžného vládnutî) a (c) decentralizace demokracie (participace občanské společnosti a různých marginalizovaných skupin, lokální demokracie). Navzdory tomu, že se Blokker snaží propojit svou ideální teorii s konkrétními návrhy, zůstává otázkou, nakolik jeho občanský či demokratizující konstitucionalismus představuje vlastní teoretickou pozici, která by se svou propracovaností mohla rovnat výše zmíněným variantám právního konstitucionalismu, nebo zda se jedná pouze o eklektický prrístup (vytvořený z toho nejlepšího z daných variant za konkrétním účelem, tj. aby vysvětlil krizi politiky ve středoevropských zemích a reagoval na ni). To však bude záviset na dalším vývoji Blokkerova zájmu, tj. zda se bude ubírat spíše normativně a takovou variantu nabídne, či empiricky, čemuž nasvědčuje jeho dosavadní vědecká produkce.

Už tento přehled jednotlivých současných konstitucionalismů je velkým př́nosem Blokkerovy práce, a proto jsem o něm - vzhledem $\mathrm{k}$ absenci odpovídajícího diskursu v českém prostředí - pohovořil takto rozsáhlým zpơsobem. Již zde je ale třeba upozornit, že možným problémem Blokkerovy typologie může být vymezení právního konstitucionalismu, které se děje většinou skrze jeho charakterizaci odpůrci než skrze sebeintepretaci jeho vlastních proponentı̊. Proto se právní konstitucionalismus nutně dostává do defenzívy: zatímco zástupci ostatních př́stupů nabízejí ideální teorii, tento prostor je právnímu konstitucionalismu upřen. Není navíc jasné, kdo by kromě Ronalda Dworkina či amerických originalistů (sluší se nicméně připomenout, že ti přenechávají demokratickým většinám více záležitostí $\mathrm{k}$ řešení než zastánci tzv. živoucí ústavy) do tohoto príistupu patřil: Jak by se Blokker vyrovnal s různými konstitucionalisty typu Stephena Holmese, kteří napětí mezi demokracií a konstitucionalismem nevidí (Holmes 1997), 
nebo autory zdưrazňujícími sou-piovodnost jejich zakládajících filosofiî? $?^{3}$ A co všichni ti autoři, kteři konstitucionalismus nepovažují jen za omezující, ale naopak lepší politiku umožňující (enabling) instrument? A co zástupci německé doktríny, kteří v ústavách vidí objektivní systém hodnot integrujících společnost a kterým je tak veškerý formalismus či technokratický přístup cizí? A konečně i u takových vehementních zastánců konstitucionalismu, mezi které patřil Walter F. Murphy, se udržování ústavních demokracií pojí se starostí o vytváření občanů, tj. o artikulaci liberálně-demokratických hodnot občanům, aby se u nich podpořily náležité „,návyky srdce“. Vždyt' pro tyto konstitucionalisty ústava nikdy nebyla jen „právnickým dokumentem“, nýbrž naopak něčím, co by mělo formovat život celé pospolitosti (Murphy 2008: 329-536). Nejsou proto dnešní problémy do značné míry způsobeny absencí výchovy o ústavních základech naší pospolitosti, tj. že ústavní demokracie nebyly schopny, resp. nevěnovaly dostatečnou pozornost právě artikulaci zakládajících hodnot a podpoře pocitů a postojů, které by jim odpovídaly? Ostatně právní konstitucionalisté (vůbec termín konstitucionalismus nebyl př́liš užíván a ani podrobně rozebírán) v českém intelektuálním i právnickém prostředí zase tak prominentní místo neměli; naopak lidská práva i ústavní soudnictví byly i jsou často „ryzími právníky“ zesměšňovány, a to i proto, že ti, kdo se s nimi při výkonu moci identifikovali, neprosazovali z hlediska Blokkerovy logiky paradoxně - „technokratickýc přístup k řešení právních př́padů (tj. zdůrazňovali hledání individuální spravedlnosti a rozhodně se vymezovali vưči formalismu převážně civilistických - občanskému právu se věnujících - právníků). Navíc politické strany, volební systémy či obecně reprezentativní demokracie v českém podání byly předmětem daleko větší reflexe než ústřední konstitucionalistické hodnoty a principy (např. první kvalitní komentář k Listině základních práv a svobod vznikl až v roce 2012). Jestliže tedy byla podceněna (občanská) výchova zaměřená na pochopení ústavních základů nových liberálních demokracií, nebyl by spíše jistým řešením pokus o její širší zavedení, podobně jako byly na mnoha amerických univerzitách rozvinuty různé vzdělávací programy týkající se ústavy?

Chápat právní konstitucionalismus jako jednu z hlavních příčin krize zní na první pohled dost bizarně. Lze se totiž domnívat, že konstitucionalistické instituce nebyly vůbec tím, co by mělo v politice těchto zemí (snad s výjimkou Mad’arska) takovou váhu, aby mohlo sloužit jako rozhodující proměnná dnešní krize. Ostatně, jak ukázal na př́kladu Spojených států amerických Mark Tushnet (2010), ústavní soudy obvykle nerozhodují o těch nejzásadnějších politických otázkách; hlavními aktéry ústavních změn jsou politici a politické strany. Nebylo by myslím nikterak těžké ukázat, že ani vliv českého Ústavního soudu na politiku nebyl zase až tak zásadní. Mnohem věrohodnější se zdá to, že za úpadkem demokratické politiky a rostoucím skepticismem občanů stojí, jak tvrdili mnozí „právní konstitucionalisté“, v daleko větší míře selhání samotných jejích elit než chování konstitucionalistických ústavních soudů, jež se spíše snažily o nápravu těchto selhání. Ústavní (i mnohé jiné) soudy jsou totiž nuceny reagovat na hypertrofii normotvorby, při níž jde kvantita na úkor kvality. Reálné naplňování formálních pravomocí (nejen ústavních) soudů, která by měla vyúst’ovat v judicializaci politiky, je možno vnímat spíše optikou selhávání demokratické strany mince, nikoliv jako její hlavní příčinu. (Perverzně se však i ušlechtile jednající Ústavní soud může stát „př́činou“ různých dysfunkcí, jestliže se na něj demokraticky legitimované instituce spolehnou při „,vychytávání“ různých problémů a rezignují

\footnotetext{
3 Tam by šlo zařadit takové autory jako Jürgen Habermas či velkého italského právního teoretika Luigiho Ferrajoliho. Je signifikantní, že ani česká doktrína nějaké napětí mezi demokracií a ústavním soudnictvím, resp. právním státem, nespatřovala. Demokracii je podle ní nutno chápat materiálním způsobem; srov. nález Ústavního soudu ČR sp. zn. Pl. ÚS 29/11 či odlišné stanovisko soudkyně Elišky Wagnerové k nálezu sp. zn. Pl. ÚS 73/04.
} 
na standardy dobré normotvorby. Každopádně ústavní soudy vystupují spíše v roli „hasiče“ nebo „elektrikáře“.) Blokkerova práce nicméně směřuje trochu jiným směrem: za hlavními problémy spíše stojí institucionální (a možná i mentálnî) rámec právního konstitucionalismu, nikoliv určité jednání konkrétních konstitucionalistických institucí, jelikož i ty se vždy pohybují již v určité struktuře, která ve středoevropských zemích nebyla nakloněna participaci lidu na vládnutí. Jinak řečeno, není-li ústavní výchova doprovázena praktickou zkušeností politické participace, o jejím vlivu na člověka lze pochybovat.

V rozsáhlejší, empirické části své práce se pak Blokker věnuje výsadnímu postavení právního konstitucionalismu (kap. 3), zárodkům a jistým, ačkoliv dosti omezeným formám občanského konstitucionalismu (kap. 4 a 5) a tlaku, pod který se zkoumané ústavní demokracie dostaly v souvislosti s př́istoupením k Evropské unii (kap. 6). Blokker upozorňuje, že prŕlišná orientace na západní standardy totiž nemusí brát dostatečně v potaz lokální faktory a napětí prúitomné v procesu demokratizace. Navíc zastánci ústavních soudů věrili tomu, že lze čistě na základě lidského rozumu odhalit správné chápání základních práv. Ústavní soudnictví bylo přebráno zcela neproblematicky, přestože se ohledně jeho legitimity i zpo̊sobu rozhodování vede na „Západě“ vzrušená debata. Jako někdo, kdo je poměrně dobře obeznámen s rozhodovací činností i fungováním českého Ústavního soudu, ovšem musím vyjádřit jisté politování nad tím, jak malá pozornost je činnosti ústavních soudů věnována, jelikož analýza zůstává většinou na formální rovině institucí; ke konkrétním rozhodnutím, která se svým způsobem také vyjádřila k (věčnému) napětí mezi demokracií a konstitucionalismem, toho již ovšem mnoho neříká.

Kapitola 3 zůstává na úrovni nastavení institucí, aniž by hlouběji zkoumala, jak extenzivně ústavní soudy vychylovaly dané země k právně konstitucionalistickým hodnotám, nebo zda naopak svou zdrženlivostí nechávaly dostatečný prostor demokratickým většinám, př́padně $\mathrm{v}$ některých rozhodnutích se explicitně pokoušely přispět ke kvalitě demokratických procesů a zdưrazňovaly ctnosti demokratické participace. Zde by pak nebyla klíčová toliko analýza konkrétních kroků ústavních soudů, nýbrž též analýza odůvodnění jejich rozhodnutí, stejně jako toho, jakým způsobem se klíčová rozhodnutí podílela na formování veřejného diskursu. Přes tyto poznámky je nicméně nutno připustit, že tento postup je Blokkerem předznačen již $\mathrm{v}$ úvodu, v němž uvádí, že v této práci jen vykreslí formálně ústavní obraz, a to z pohledu demokratické participace, aniž by pokryl implementaci ústav a jejich interpretaci různými aktéry v terénu. Je však otázkou, jak velké závěry lze činit z formálního nastavení institucí pro současnou krizi demokracie, jestliže popis konkrétního mechanismu, jak by $\mathrm{k}$ výslednému stavu měli přispět jednotliví hráči právního konstitucionalismu, jakkoli vědomě, v Blokkerově práci chybí. Jinak řečeno, stejně jako formální ústava nemusí (ještě) odpovídat způsobu života dané obce (tj. ústavě v onom nejširším, aristotelském smyslu slova), tak ani nelze bez analýzy konkrétního působení právního konstitucionalismu dobře určit, jak moc a prŕípadně zda vůbec byl důležitou prríčinou krize demokracie.

Přestože Blokker některé další příčiny krize (krize reprezentativní demokracie atd.) určuje, nerozebírá-li mechanismus působení (jeho) rozhodující prř́činy - právního konstitucionalismu -, nevyznívá jeho analýza nakonec př́liš přesvědčivě. Existují navíc různé alternativní výklady upozorňující naopak na slabost, nikoliv sílu právního konstitucionalismu v dnešním světě. Tak např. podle Wolina dochází $\mathrm{k}$ nové distribuci moci, která činí ústavy stále méně relevantními, protože nejsou schopny kontrolovat režim, jehož zdrojem moci je kapitál, technologie či věda (Wolin 2008: 100). Ostatně i nedávné tvrzení Petra Druláka, ačkoliv by jeho východiska i závěry 
měly být též podrobeny empirickému zkoumání, vypadá vzhledem k příčinám změn současné politiky prima facie daleko přesvědčivěji. Jednou z příčin (krize) může být totiž to, že

\begin{abstract}
"[C] eské vládní instituce dnes prénášeji jak konkrétni rozhodnutí, tak i formulace dloubodobých strategii na soukromé aktéry, kteř̀ v dané oblasti podnikaji (...). Tím, že česká tř̌ñ demokracie żtratila pojem veréjného zájmu, zmènila se na oligarchii, která popirá základni hodnotu rovnosti. Soustrédèním mocenskéch zdrojů vznikla relativnè úzká a uzavrená privilegovaná skupina oligarchì, keterá ovládla pospolitost. Smyslem české politiky se stala obsluba oligarchie. Účast ve volbách ztratila smysl (...)“ (Drulák 2012: 250).
\end{abstract}

Zásadní mocenská rozhodnutí se tak odehrávají mimo procedury regulované ústavou; šlo by tak spíše o selhání ústavy, resp. právního konstitucionalismu, ovšem nikoliv pro jeho dominanci, ale naopak pro nedostatečnou dominanci (tj. nikoliv pro jeho sílu, ale naopak slabost, ke které pak přispělo mj. jeho nepochopení elitami i širší veřejnostî). Proto lze také současnou krizi ústavních demokracií označit za krizi právního konstitucionalismu, kdy na hlavní cíle, které klíčoví političtí aktéři sledují, ústavy stále méně působí. Na druhou stranu formální nastavení institucí vymezilo již od začátku jisté pole možností, kdy varianty konstitucionalismu nakloněnější větší účasti lidu nebyly vyzkoušeny. Je nicméně velice obtîžné předvídat další vývoj politiky, jestliže by byly tyto alternativy přijaty. Zde se budeme muset obrátit $\mathrm{k}$ alternativním teoretickým pozicím a na jejich základě oponovat Blokkerově tvrzení, že za krizí, projevující se nízkou participací, stojí především nízká institucionalizace participace (kvůli níž též nedošlo k osvojení konstitucionalistických hodnot). Přesto participaci nakloněné varianty nevycházely po roce 1989 $\mathrm{z}$ až tak špatné výchozí pozice. Určité místo ve veřejném diskursu měly a právě zárodkům i dalšímu hledání občanského konstitucionalismu se Blokker věnuje v dalších dvou částech práce (kap. 4 a 5 ).

Ačkoliv u disidentů za komunistického režimu hrála lidská práva velkou symbolickou úlohu, nebyla výlučnou intelektuální výbavou. Již v rámci disidentského hnutí lze spatřovat zárodky demokratického konstitucionalismu, který určitou, byt' omezenou roli ve stredoevropských zemích hrál. Bohužel se ale do procesu vytváření Ústavy nepodařilo vtáhnout širší masy, které jí tak zůstaly odcizeny. Tyto disidentské tradice, zdůrazňující občanskou angažovanost, se ale př́liš neprojevily na možnostech účasti občanů při provádění ústavních změn. Ani tradice př́mé demokracie nejsou př́liš silné; výraznější tendence byly jen směrem institucionalizaci regionálních a lokálních forem vládnutí, ale ani zde výsledky nebyly nijak zvláště uspokojivé. Podle Blokkera se středoevropské ústavní demokracie navíc dostaly pod tlak, který má př́činu jednak v právním konstitucionalismem nasáklé evropské integraci, jednak v domácím resentimentu vưči právnímu konstitucionalismu (kap. 6). Evropská integrace s sebou přináší perverzní důsledky, které se projevují mj. v technokraticko-instrumentálním pohledu na demokracii a právní stát a v redukci demokracie pouzena reprezentativní formy. S integračním procesem byl spjat i zapeklitý problém suverenity: jakmile se dostaly nové zrozené demokracie ze sovětského područí a mohly si samy vládnout, hned se objevily podmínky, které je nutily omezit autonomní prostory vládnutí. Resentiment $\mathrm{k}$ právnímu konstitucionalismu pak nabral nejvýraznějších podob v Mad’arsku a Rumunsku, nevyústil však v institucionalizaci nějaké více participační a demokratičtější formy konstitucionalismu, nýbrž $\mathrm{v}$ př́padě Mad’arska $\mathrm{k}$ problematické formě komunitaristického konstitucionalismu (či dokonce proti-konstitucionalismu). 
Podle Blokkera jsou tu tedy indicie, že (také) právní konstitucionalismus přispěl ke zhoršení problematického stavu demokracie a nedostatku zakořenění ústavní demokracie. Mezi perverzní důsledky právního konstitucionalismu (asi) patřilo rozložení některých klíčových dimenzí demokracie, např. rozvoje demokratické politické kultury, ducha občanské participace a dynamických a kritických interakcí mezi ústavou, politikou a širší společností. Kvưli tomu je přilnutí veřejnosti $\mathrm{k}$ ústavním hodnotám slabé a nikdo není veřejně ochoten diskutovat o základních hodnotách, které drží společnost pohromadě. Nevytvořila se tu nějaká forma ústavního patriotismu. Ta by mohla vzniknout pouze tehdy, pakliže by byly základní hodnoty neustále předmětem společenské debaty. Ústavy těchto zemí nebyly participaci nijak zvláště nakloněny. Proto Blokker volá po oživení tradice občanského konstitucionalismu.

Snaha občanského či demokratizujícího konstitucionalismu po oživení politické participace a angažovanosti nicméně bude v postkřest’anském světě vždy obtížná, protože řecké přecenění politiky bylo navždy přerušeno církví (Milbank 2014). Na její místo dnes nastoupila občanská společnost, která nabízí různé možnosti pro realizaci člověka a jeho zájmů. Církev je dnes toliko jednou z jejích součástí. Veškeré pokusy, vycházející z republikánské tradice, budou v podmínkách moderní, postkřest’anské společnosti přinášet svým přínivcům vždy určité zklamání, jelikož budou narážet na individualismus občanů. Byt' se v určitých historických momentech může snad politika dostat do centra pozornosti a zájmu všech, př́liš občanů nesní o oživení forem prímé demokracie ani o tom, že by byli do politiky více vtaženi (Rosanvallon 2008: 354). ${ }^{4}$ Proto od nich nelze ani očekávat, že by se snad chtěli a museli kontinuálně podílet na reformulaci nejvyšších právních norem, po čemž volá Blokker, byt' jistý prostor pro institucionalizace některých mechanismů doporučovaných Blokkerem zde jistě je (otázkou je ale jejich míra). Čas věnovaný vládnutí by byl až přiliš velkou obětí, protože by bral prostor sledování dalších cílů. Navíc by $\mathrm{v}$ rámci těchto procesů nutně musela vznikat rozdělení mezi lidmi i frakcionářství. Přitom právě k názorové polarizaci cítí „demokratický člověk“ největší averzi. Zkušenost $\mathrm{s}$ politikařením by $\mathrm{v}$ př́padě větší politické angažovanosti a participaci lidu mohla být ještě živějšíi, čímž by se navrhované řešení mohlo stát horším než řešený problém. A konečně zůstává otázkou, proč a jak by vize občanského či demokratizujícího konstitucionalismu, i když by byla institucionalizována, mohla přesvědčit „posledního člověka“ (Fukuyama 2002: 273-318), že skrze politickou angažovanost a participaci lze realizovat hluboké touhy jeho já, když má základní zdroje díky právnímu konstitucionalismu zajištěny. Ochuzuje se člověk neangažovaností v politice vůbec o něco podstatného? A jaký je status dobra účasti na životě pospolitosti v životě jako celku? Když už se tak volá po politické angažovanosti a participaci, nejde přece nejen o dobro systému, ale i (a možná především) o dobro, co by skrze ně člověk mohl zakusit. Vždyt' své já a své soukromé zájmy mohu překračovat v nejrůznějších občanských sdruženích, která jsou ostatně tzv. „školami svobody“ pro účast na vyšší politické úrovni. Proč by se mělo co nejvíce lidí přímo účastnit této vyšší politiky? Ač Blokker (a jemu podobní autoři) sní o větší politické angažovanosti a participaci občanů, měl by se pokusit nabídnout jim přesvědčivější důvody.

Blokker též podceňuje zpo̊sob, jak by mohly být ústavní soudy vnímány jako jeho spojenci. $\mathrm{Na}$ rozdíl od běžných politiků totiž daleko lépe obohacují demokratickou deliberaci (Rosanvallon

\footnotetext{
${ }^{4}$ Nadto je klasickou námitkou proti republikánským koncepcím, že na člověka kladou až př́liš vysoké nároky. Lze asi těžko od občanů očekávat, že by se měli a vůbec mohli vyjadřovat ke všemu v podmínkách složitých postindustriálních společností.

${ }^{5}$ Tento poslední člověk se zabývá pouze sám sebou, což s sebou přináší marasmus sobeckého hédonismu i rozklad společenství. Jeho život se odehrává ve fyzickém bezpečí a materiální hojnosti, a proto lidé změkli. Ve světě posledního člověka ideály ztratily význam, politika se mění ve správu.
} 
2008: 222 an.). Právě absence rozboru fungování ústavního soudnictví v těchto zemích mu brání, aby kladněji hodnotil jejich roli. Pozitivně mohou aktivizovat kolektivní pamět' dané společnosti, protože se skrze jejich činnost neustále aktualizují principy, na nichž byla daná politická jednotka postavena. Skutečnost, že tyto principy nebyly po pádu komunismu podrobeny konstitutivní sankci lidu, je přitom často negativně vnímána samotnými (právními) konstitucionalisty. Absenci ústavního patriotismu nicméně vnímají jako kulturní, nikoliv institucionální problém (srov. obdobně Barber 2010: 19-22): Politické elity samy nebyly schopny oddanost hodnotám konstitucionalismu přetavit do koherentnější politické doktríny a tu následně pře(d)ložit lidem. Státnické selhání elit se projevilo v neschopnosti oslovit veřejnost skrze nějaký politický program (Drulák 2012: 265-268). Místo vypracování určité konzistentnější představy o fungování státu je navíc pro demokratické elity daleko typičtější nadbíhání veřejnému mínění. Výzkumy veřejného mínění se svým způsobem mohou stát náhražkou voleb. Vláda ovšem není schopna často činit populární věci, protože žádá od občanů povinnosti a obět’ (Mansfield 1991: 189), jíž se demokratický člověk vyhýbá; líbí se mu to, co od něj nic nežádá, a proto je pro něj, jak ukázal Tocqueville, tak typickou ctností soucit. Nadšení pro participativnější formy demokracie se proto může minout účinkem, protože nabízí velké pole pro tradiční problémy historicky spjaté s vládou lidu: populismus (dovolávající se soucitu), frakcionářství a tyranské většiny nijak neomezené ústavními formami. Výsledkem mohou být až přiliš krátkozraká, ba dokonce nebezpečná politická rozhodnutí. A nadto jsou současné demokracie, jak poznamenal Pierre Rosanvallon (2008: 229), daleko více ohrožovány tímto kultem př́tomnosti než uvězněním v právních formách. Tento kult se projevuje $\mathrm{v}$ explozi různých právních regulací, které mnohdy ani nenaplňují požadavky formálního právního státu. Tím se aktualizují pravomoci ústavních soudů, a proto mohl být právní konstitucionalismus považován za tak důležitý fenomén i politickou vědou. Je otázkou, zda by Blokkerem navrhované řešení nevedlo jen $\mathrm{k}$ další produkci právních norem, které by ještě více udusily společnost, a zda by soudy proto nemusely volit obdobné interpretační techniky, jaké dnes užívá právní konstitucionalismus.

Přes tyto kritické výtky si Blokkerova práce zaslouží v našem prostředí velkou pozornost, jelikož bere vážně problém, kterému dnesČeská republika čelí. Na druhou stranu vychází až př́liš z jasného normativního východiska, které trochu zkresluje pohled na fenomén, jímž se zabývá, protože pak nebere $v$ potaz další, možná ještě důležitější faktory, které jsouve hře. Ty sice v úvodu zmiňuje, ale protože je ve své práci př́liš nereflektuje, vypadá výsledek jeho práce dosti jednostranně. Při čtení Blokkeerova textu a tváři v tvář otázce, které čelíme, se mi nejvíce vybavovaly teze $\mathrm{z}$ díla Alexise de Tocquevilla: Zatímco v prvním díle Demokracie v Americe spatřoval hlavní nebezpečí demokracie $\mathrm{v}$ tyranii většiny, přičemž byl skeptický, že se ústavě (tj. jinak řečeno modernímu konstitucionalismu), založené na principu reprezentace a brzd a protiváh, podařilo najít efektivní řešení tohoto problému (ten se mimochodem nejvíce projevuje v rríši myšlení, omezením nezávislosti ducha), v druhém díle spatřuje hlavní hrozbu $\mathrm{v}$ demokratickém despotismu, který je spojen s individualismem a nechává lidi ve věčné politické nedospělosti. $Z$ apatických občanů se stává stádo podobných a rovných lidí sledujících malé radosti a potěšení. Nad tímto stádem pak bdí ona protektorská moc. Nejvíce mne ovšem Tocqueville fascinuje $\mathrm{v}$ tom, jak byl schopen proniknout do duše demokratického člověka. Nikoliv jen $\mathrm{k}$ formálním institucím, ale $\mathrm{k}$ mravům, jež demokratického člověka charakterizují, by měla být politická věda vnímavá. Krize současných demokracií možná není jen (a ani v prvé řadě) 
krizí institucí, nýbrž myšlenek, citů a mravů postojů a v širším slova smyslu kultury. ${ }^{6}$ Proto je výlet do duše demokratického člověka něčím tak důležitým, něčím, na co čekáme.

\section{Literatura}

Barber, Sotirios A. (2010): „Constitutional Failure: Ultimately Attitudinal.“ In: The Limits of Constitutional Democracy. Eds. Jeffrey K. Tulis, a Stephen Macedo. Princeton: Princeton University Press, 13-28.

Drulák, Petr (2012): Politika nezájmu: Česko a Západ v krizi. Praha: SLON.

Fukuyama, Francis (2002): Konec déjin a poslední člověke. Praha: Rybka Publishers.

Fukuyama, Francis (2006): Velký rozurat. Lidská prirrozenost a rekonstrukce společenskébo rádu. Praha: Academia.

Holmes, Stephen (1997): Passions and Constraint: On the Theory of Liberal Democracy. Chicago: The University of Chicago Press.

Mansfield, Harvey C. (1991): America's Constitutional Soul. Baltimore: The Johns Hopkins University Press.

Milbank, John (2014): "Education into Virtue: Against the Tyranny of Modern Mass Education." Religion and Ethics, on-line (http://www.abc.net.au/religion/articles/2014/05/09/4001516.htm).

Murphy, Walter F. (2008). Constitutional Democracy: Creating and Maintaining a Just Political Order. Baltimore: The Johns Hopkins University Press.

Murphy, Walter F., James E Fleming, Sotirios A. Barber, Stephen Macedo (2008): American Constitutional Interpretation. New York: Foundation Press.

Rosanvallon, Pierre (2008): La légitimité démocratique. Paris: Seuil.

Tushnet, Mark (2010). Why the Constitution Matters. New Haven: Yale University Press.

Wolin, Sheldon S. (1994): „Fugitive Democracy.“ Constellations 1(1): 11-25. DOI: 10.1111/j.14678675.1994.tb00002.x

Wolin, Sheldon S. (2004): Politics and Vision: Continuity and Innovation in Western Political Thought. Princeton: Princeton University Press.

Wolin, Sheldon S. (2008): Democracy Incorporated: Managed Democracy and the Specter of Inverted Totalitarianism. Princeton: Princeton University Press.

\footnotetext{
${ }^{6}$ Tak např. Francis Fukuyama uvádí, že „formální právní a silné politické a ekonomické instituce jsou sice zásadně důležité, samy o sobě však nejsou zárukou úspěšného chodu moderní společnosti. Liberální demokracie vždy závisela na řádném fungování určitých společných (sdílených) kulturních hodnot.“ $Z$ tohoto úhlu pohledu „kultura bezuzdného individualismu, $\mathrm{v}$ níž se porušování pravidel stává jediným pravidlem (od všech ostatních se „osvobodila“), přináší vážné problémy“ (Fukuyama 2006: 22-27). V tomto smyslu by šlo dále zkoumat nap̌r. proměny klíčových ústavněprávních konceptů: v prípadě lidské důstojnosti by to byl napřx. přechod od původního (katolického) pojetí $\mathrm{k}$ dnešnímu pojetí libertariánskému
} 